\title{
PELATIHAN PENGGUNAAN EJAAN YANG DISEMPURNAKAN \\ DAN KALIMAT EFEKTIF PADA PENULISAN SURAT RESMI BAGI GURU SEKOLAH DASAR DI JAKARTA TIMUR
}

\author{
Asep Supriyana ${ }^{1)}$, Gres Grasia Azmin ${ }^{2)}$, Reni Nureriyani ${ }^{3)}$, Aulia Rahmawati ${ }^{4)}$ \\ Jurusan Bahasa dan Sastra Indonesia Fakultas Bahasa dan Seni \\ Universitas Negeri Jakarta
}

\begin{abstract}
ABSTRAK
Pelatihan ini bertujuan untuk meningkatkan kemampuan guru SD di Wilayah Jakarta Timur dalam menggunakan ejaan yang disempurnakan dan kalimat efektif pada penulisan surat resmi. Berdasarkan hasil tes awal, peserta yang memiliki kemampuan menulis surat resmi dengan kriteria kejelasan isi surat sebanyak $70 \%$, kejelasan urutan surat sebesar $65 \%$,

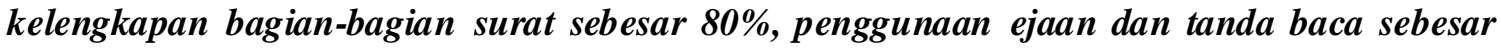
$70 . \%$, dan penggunaan kalimat efektif sebesar $75 \%$.
\end{abstract}

Kata Kunci : Surat Resmi, Ejaan yang Disempurnakan, Kalimat Efektif

\section{PENDAHULUAN}

Bahasa merupakan alat komunikasi antara anggota masyarakat berupa simbol bunyi yang dihasilkan oleh alat ucap manusia. Selain itu bahasa juga merupakan sistem komunikasi yang mempergunakan simbol-simbol vokal (bunyi) ujaran yang bersifat arbiter. Dengan demikian, bahasa adalah alat komunikasi manusia yang menggunakan simbol-simbol yang bersifat arbriter.

Ejaan sendiri menurut KBBI (1998) merupakan kaidah-kaidah cara menggambarkan bunyi-bunyi (kata, kalimat, dsb) dalam bentuk tulisan (huruf-huruf) serta penggunaan tanda baca. Ejaan ini merupakan hal yang sering terabaikan oleh pengguna bahasa. Padahal pada prinsipnya, seorang manusia ketika berjalan, tidak akan terjatuh karena gunung yang tinggi; ia akan jatuh karena kerikil kecil. Dengan demikian, EyD merupakan aspek yang sangat penting khususnya dalam penulisan surat resmi.

Surat resmi ialah surat yang dipergunakan untuk kepentingan yang bersifat resmi, baik yang ditulis dari perseorangan, instansi, lembaga, maupun organisasi. Surat menyurat sudah tidak dapat dipisahkan lagi dari kelembagaan. Oleh Karena itu, tata aturan yang benar diperlukan agar pesan yang ingin disampaikan melalui surat dapat sesuai dengan yang dipahami oleh penerima surat.
Sekolah merupakan lembaga pendidik yang selalu berkomunikasi dengan berbagai pihak seperti orang tua, dinas, sekolah lain, dan lain-lain. Untuk itu, di sekolah tersebut dibutuhkan SDM yang mampu menyusun surat resmi menggunakan EyD yang tepat. EyD tersebut terkait dengan pemakaian huruf, penulisan kata, kata serapan, tanda baca, maupun pemenggalan. Selain itu juga terkait dengan kalimat efektif dan tata persuratan.

Observasi pada surat yang resmi yang beredar yang dikeluarkan oleh pihak sekolah, kami melihat masih ada kesalahan penggunaan EyD. Padahal surat merupakan media yang kerap dipakai jika sekolah ingin berkomunikasi dengan pihak lain.

Permasalahan pada pengabdian ini terkait dengan kekurangpahaman guru-guru mengenai EyD dan kalimat efektif khususnya dalam persuratan dinas pada guru Sekolah Dasar. Adapun tujuan kegiatan ini untuk melatih guru SD di kota Jakarta Timur agar mampu menerapkan EyD dan kalimat efektif dalam penulisan surat resmi.

\section{A. Hakikat Surat Resmi}

Surat resmi ialah surat yang dipergunakan untuk kepentingan yang bersifat resmi, baik yang ditulis dari perseorangan, instansi, lembaga, maupun organisasi. Contohnya : surat undangan, surat pemberi- 


\section{P-ISSN : 0216-7484 \\ DOI : doi.org/10.21009/sarwahita.121.02}

tahuan, dan surat edaran. Ciri-ciri surat resmi, seperti berikut.

1) Menggunakan kepala surat jika yang mengeluarkannya adalah lembaga atau organisasi

2) Menggunakan nomor surat, lampiran, dan perihal

3) Menggunakan salam pembuka dan penutup yang lazim atau resmi, seperti: Assalamualikum, dengan hormat, hormat kami

4) Menggunakan bahasa dengan ragam resmi atau baku

5) Menggunakan cap/stempel jika berasal dari sebuah organisasi atau lembaga resmi

6) Penulisan surat mengikuti format surat tertentu (tidak bebas)

\section{B. Penggunaan Ejaan yang Disempurnakan}

Bahasa tulisan sebagai sebagai salah satu bentuk wacana yang menggunakan bahasa sebagai mediumnya mensyaratkan seorang penulis untuk menguasai kaidah-kaidah bahasa, khususnya penggunaan EYD. Karena dengan pengusaaan terhadap kaidah EYD, dapat dipastikan pesan informasi yang disampaikan dalam tulisannya dapat dengan mudah dipahami oleh pembacanya. Berkaitan dengan ini, Tarigan (1984: 21) menyatakan, "Menulis adalah menurunkan atau melukiskan lambanglambang grafik, yang menggambar-kan suatu bahasa yang dipahami seseorang, hingga orang lain memahami lambang-lambang grafik tersebut kalau mereka memahami bahasa dan gambaran grafik itu".

Surat resmi sebagai salah satu bentuk karya berbentuk tulisan tampaknya patut dicermati lebih jauh khususnya dalam kaitan penggunaan EYD yang terdapat didalamnya. Berbagai macam bentuk surat resmi diantaranya seperti surat lamaran, surat permohonan, surat perjanjian dan sebagainya, untuk memenuhi fungsi dan tujuannya sebagai alat komunikasi juga tidak terlepas dari unsur penggunaan EYD. Bahkan dalam surat resmi, format penulisan surat pun juga menjadi salah satu tolok ukur yang penting.

Surat resmi sebagai bentuk alat komunikasi pengganti dan menggunakan bahasa dalam bentuk tertulis harus tersajikan dengan jelas, disamping harus memperhatikan isinya dengan baik. Dan untuk memperoleh kejelasan dan kebaikan isi dari sebuah surat resmi, salah satunya perlu ditunjang oleh penguasaan terhadap penggunaan kaidah EYD yang baik pula. Dengan demikian, pihak pembaca atau penerima surat dapat dengan jelas pula memahami isi dan maksud dari surat tersebut.

Di sisi lain, dalam kaitan penulisan surat resmi juga pada praktiknya seringkali didapati kesalahan, Kesalahan-kesalahan itu antara lain berupa susunan kalimat yang tidak lengkap dan berbelit, penggunaan tanda baca yang tidak perlu atau berlebihan, ejaan yang tidak sesuai dengan EYD, pemakaian istilah asing yang tidak perlu, tata bahasa yang tidak teratur, bahkan penggunaan bentuk atau model surat resmi yang tidak menentu. Oleh karena itu, sebagai upaya untuk mengoptimalkan penulisan surat resmi yang memenuhi syarat dan kaidah bahasa, perlu dilakukan studi yang lebih mendalam tentang penggunaan EYD dalam surat resmi yang dibuat oleh siswa di sekolah pada saat mempelajari penulisan surat menyurat. Hal ini bertujuan untuk memperkecil tingkat kesalahan yang mungkin terjadi dalam penulisan surat resmi.

Kesalahan berbahasa dan kesalahan penulisan kaidah Ejaan Yang Disempurnakan (EYD) semestinya harus dihindari dalam penulisan surat resmi. Dalam penulisan surat resmi, kesalahan Ejaan Yang Disempurnakan (EYD) biasanya meliputi kesalahan pemilihan kata, kesalahan pemakaian huruf kapital, kesalahan pemakaian tanda baca dan kesalahan kata/istilah. Upaya untuk mengoptimalkan penulisan surat resmi yang memenuhi syarat dan kaidah bahasa, perlu dilakukan studi yang lebih mendalam tentang penggunaan EYD dalam surat resmi. Hal ini bertujuan untuk 
memperkecil tingkat kesalahan yang mungkin terjadi dalam penulisan surat resmi.

Dalam Buku Seri Penyuluhan I tentang Ejaan Yang Disempurnakan (EYD) dinyatakan bahwa ejaan adalah kaidah-kaidah cara menggambarkan bunyi-bunyi bahasa (kata, kalimat) dalam bentuk tulisan (huruf-huruf dan tanda baca) (Depdikbud, 1992 : 1). Pada praktiknya penggunaan kaidah ejaan dalam bahasa tulis sangatlah penting. Hal ini terkait dengan aspek kebakuan bahasa, termasuk untuk bahasa Indonesia. Karena jika tidak, maka pemakaian bahasa Indonesia sebagai bahasa nasional pun akan mengalami ketidakbakuan. Hal ini sejalan dengan apa yang dikemukakan oleh Arifin (1993:10) menyatakan bahwa jika kaidah ejaan digunakan dengan cermat, kaidah pembentukan kata diperhatikan dengan seksama, dan penataan penalaran ditaati dengan konsisten, pemakaian bahasa Indonesia dikatakan benar.

Sebaliknya, jika kaidah-kaidah bahasa itu kurang ditaati, pemakaian bahasa tersebut dianggap tidak benar/tidak baku. Jika ditinjau dari ruang lingkupnya, ejaan mencakup lima aspek yang diatur, yaitu 1) pemakaian huruf, 2) penulisan huruf, 3) penulisan kata, 4) penulisan unsur serapan, dan 5) pemakaian tanda baca.

Dalam hal pemakaian huruf, hal ini membicarakan tentang bagian-bagian dasar dari suatu bahasa yang mencakup abjad, vokal, konsonan, suku kata, dan nama diri. Sedangkan dalam hal penulisan kata/kalimat dibicarakan tentang perubahan dan penggunaan huruf dalam tata tulis, seperti huruf kapital dan huruf miring. Untuk penulisan kata, inti yang dibicarakan adalah mencakup bidang morfologi dengan segala bentuk dan jenisnya, seperti kata dasar, kata turunan, kata ulang, gabungan kata, kata ganti, kata depan, kata sandang, partikel, singkatan dan akronim, dan angka serta lambang bilangan.

Dalam penulisan unsur serapan membicarakan aspek-aspek yang berkaitan dengan kaidah cara penulisan unsur serapan terutama kosa kata atau perbendaharaan kata yang berasal dari bahasa asing. Sedangkan pemakaian tanda baca membahas tentang teknik penerapan tanda baca dalam penulisan yang masing-masing mempunyai kaidah tersendiri, seperti tanda titik (.), tanda koma (,), tanda titik koma (;), tanda titik dua (:), tanda hubung (-), tanda pisah (--), tanda elipsis (...), tanda tanya (?), tanda seru (!), tanda kurung $((.)$.$) , tanda petik ("..") dan tanda garis miring$ (/).

\section{Penggunaan Kalimat Efektif dalam Surat Resmi}

Kalimat efektif adalah kalimat yang dapat mengungkapkan gagasan pemakainya seacara tepat dan dapat dipahami oleh pendengar/pembaca secara tepat pula. Kalau gagasan yang disampaikan sudah tepat, pendengar atau pembaca dapat memahami pikiran tersebut dengan mudah, jelas dan lengkap seperti apa yang dimaksud oleh penulis atau pembicaranya. Akan tetapi, kadangkadang harapan itu tidak tercapai. Misalnya, ada sebagian lawan bicara atau pembaca tidak memahami apa maksud yang diucapkan ata yang dituliskan. Supaya kalimat yang dibuat dapat mengungkapkan gagasan pemakainya secara tepat, unsur kalimat-kalimat yang digunakan harus lengkap dan eksplisit. Artinya, unsur-unsur kalimat seharusnya ada yang tidak boleh dihilangkan. SebaliknYa, unsur-unsur yang seharusnya tidak ada tidak perlu di munculkan.

Beberapa ahli komposisi menjelaskan bahwa yang dimaksud dengan kalimat efektih adalah:

1) Kalimat yang benar dan jelas dan dengan mudah dipahami orang lain.

2) Disusun secara sadar untuk mencapai daya informasi yang diinginkan penulis terhadap pembacanya

3) Pembaca memahami apa yang disampaikan

4) Kalimat yang tepat mewakili gagasan atau perasaan penyampai pesan dan sanggup memberikan gambaran yang sama tepatnya pada pembaca atau pendengar.

5) Kalimat yang disusun dengan sadar dan sengaja untuk mencapai daya informasi yang tepat dan baik.

6) Jenis kalimat yang dapat memberikan efek tertentu dalam komunikasi. Efek yang dimaksudkan di sini adalah kejelasan informasi”.

7) tidak menggunakan kata-kata mubazir, tetapi juga tidak kekurangan kata.

8) menggunakan pengertian yang logis sejalan dengan nalar yang tepat” 
Kelengkapan dan keeksplisitan semacam itu dapat diukur berdasarkan keperluan komunikasi dan kesesuaiannya dengan kaidah.Kalimat dikatakan efektif apabila berhasil menyampaikan pesan, gagasan, perasaan, maupun pemberitahuan sesuai dengan maksud si pembicara atau penulis. Untuk itu penyampaian harus memenuhi syarat sebagai kalimat yang baik, yaitu strukturnya benar, pilihan katanya tepat, hubungan antarbagiannya logis, dan ejaannya pun harus benar.

Kalimat efektif mempunyi beberapa ciri, yaitu kesatuan gagasan, kesejajaran (paralel), kehematan, penekanan, dan elogisan.

\section{METODE PELATIHAN}

\section{A. Kerangka dan Realisasi Pemecahan Masalah}

Kegiatan P2M ini memecahkan masalah kekurangpahaman guru dan pegawai di sekolah dalam menyusun surat dinas berdasarkan tata cara penulisan surat dan penggunaan ejaan yang disempurnakan yang benar.Masalah mengenai kekurangpahaman guru dan karyawan di sekolah terhadap EyD dalam penyusunan surat dinas dipecahkan melalui rangkaian pelatihan mengenai EyD dan surat dinas. Pelatihan diselenggarakan selama 8 jam di Jakarta Timur. Pelatihan diselenggarakan pada tanggal 19 September 2015.

\section{B. Sasaran}

Sasaran yang dituju pada kegiatan pengabdian kepada masyarakat ini ialah guruguru Sekolah Dasar serta karyawan di Sekolah Dasar khususnya yang bertugas di bidang administrasi sekolah. Jumlah peserta pelatihan yang ditargetkan adalah 20 orang.

\section{HASIL DAN PEMBAHASAN}

\section{A. Perencanaan}

Perencana pelatihan dilakukan dalam tiga tahap. Yaitu:

Tahap pertama, tim berkoordinasi dengan beberapa kepala sekolah untuk menugaskan dua orang di sekolah yang dipimpinnya untuk mengikuti perltihan. Setelah berkoordinasi dengan beberapa kepala sekolah di dasar di wilayah Jakarta Timur, terkumpullah dua puluh orang peserta dari sembilan sekolah dasar yang ada di wilayah Jakarta Timur, khususnya Kecamatan Klender. Daftar peserta terlampir (lampiran 1). Selain itu, tim juga memohon izin salah satu kepala sekolah dasar untuk meminjam salah satu ruangan kelas di SD yang bersangkutan untuk digunakan sebagai tempat kegiatan pelatihan, yaitu SD Negeri Klender 22, Jalan Buaran2, RT 05/13 No. 39, Duren Sawit Jakarta Timur.

Tahap kedua, tim pun menentukan indikator dengan mengacu pada tujuan pelatihan, yaitu meningkatkan kemapuan guru sekolah dasar dalam penggunaan ejaan yang disempurnakan dan kalimat efektif pada penulisan surat resmi. Secara garis besar, indikator pelatihan dikelompokkan ke dalam dua kriteria, yaitu:

a. Kemampuan menulis surat resmi, yang terdiri dari:

1) kejelasan isi surat (mudah dipahami dan jelas gagasan surat)

2) kejelasan urutan surat (pembukaan, isi, penutup)

3) kelengkapan bagian-bagian surat (kepala surat, tubuh surat, penutup surat)

b. Penggunaan bahasa Indonesia dalam surat resmi, yang terdiri dari:

1) Penggunaan ejaan dan tanda baca

2) Penggunaan kalimat efektif

Tahap ketiga, merancang materi pelatihan dalam bentuk bahan tayang (power point). Selain itu, tim pun menyiapkan materi pendukung berupa contoh surat resmi dan surat tidak resmi. Bahan tayang dan dan materi pendukung terlampir.

\section{B. Pelaksanaan Pelatihan}

Pelaksanaan pelatihan dilaksanakan selama satu hari, yaitu Sabtu, 19 September 2015. Pelaksanaan peltihana ini dilakukan dalam tiga tahap, yaitu:

Tahap pertama, pelaksanaan tes awal. Tes ini dilakukan dalam bentuk tes unjuk kerja, yaitu semua peserta diminta untuk menuliskan kembali surat resmi yang pernah dibuat selama peserta bekerja sebagai guru sekolah dasar, dengan tujuan untuk menge-tahui kemampuan awal peserta menggunakan ejaan, tanda baca, dan kalimat efektif dalam menulis surat resmi. Berdasarkan hasil pretes, dapat digambarkan kemampuan awal peserta sebelum mengikuti kegiatan pelatihan ini sebagai berikut. Dari keseluruhan peserta, peserta yang memiliki 
kemampuan menulis surat resmi dengan kriteria kejelasan isi surat sebanyak 15\%, kejelasan urutan surat sebanyak 10\%, kelengkapan bagian-bagian surat sebanyak 10 $\%$, penggunaan ejaan dan tanda baca sebanyak $20 \%$, dan penggunaan kalimat efektif sebanyak $25 \%$.

Tahap kedua, tim melaksanakan pelatihan. Secara umum, materi pelatihan dibagi ke dalam dua jenis, yaitu (2) surat resmi dan (2) penggunakan ejaan, tanda baca, dan kalimat efektif dalam penulisan surat resmi.

Metode yang digunakan dalam penelitian ini adalah metode konvensional, yaitu paparan, diskusi, dan latihan menulis surat resmi. Materi diberikan pada pelatihan ini adalah konsep tentang surat resmi, dana penggunaan ejaan, tanda baca, dan kalimat efektif dalam penyusunan surat resmi. (materi pelatihan terlampir). Pemapan materi pelatihan disampikan dengan menggunakan media infokus (bahan tayang terlampir)

Tahap ketiga, tim melaksanakan tes akhir (postes) dalam bentuk unjuk kerja. Peserta diminta membuat surat resmi, dengan memberi pilihan jenis surat resmi kepada mereka. Jenis surat resmi yang dapat dipilih peserta adalah $\{1)$ surat undang rapat orang tua siswa, (2) surat tugas, dan (3) surat permohonan. Di antara pilihan tersebut, sebagian besar peserta memilih surat undangan $60 \%$, sedangkan sisanya memilih surat tugas sebanyak 30\% dan yang memilih surat permohonan hanya $10 \%$.

Tes akhir dilaksnakan dalam 30 menit. Berdasarkan hasil tes akhir, menunjukkan ada peningkatan jika dibandingkan dengan hasil tes awal. Setelah melalui latihan ini, kemampuan guru dalam menggunakan ejaan, tanda baca, dan kalimat efektif meningkat, yaitu kemampuan guru menulis surat dengan kriteria kejelasan isi surat sebesar 70\%, kejelasan urutan surat sebesar 65\%, kelengkapan bagianbagian surat sebesar $80 \%$, penggunaan ejaan dan tanda baca sebesar $70 . \%$, dan penggunaan kalimat efektif sebesar $75 \%$.

\section{Pembahasan}

Pelatihan ini menggunakan metode konvensional, yaitu paparan materi, diskusi, dan latihan. Walaupun menggunakan metode konvensional, perubahan kemampuan peserta pelatihan jika dibandingkan antara sebelum dan setelah mengikuti latihan cukup berbeda, bahkan peningkatannya pun cukup tinggi. Hal disebabkan oleh latar belakang profesi peserta yaitu sebagai guru. Bagi guru, menulis surat bukan hal yang baru. Kekurang yang mereka miliki dlebih disebakan oleh belum pahamnya aspek-aspek atau bagaian-bagian yang harus ada dalam surat resmi. Selain itu, pemahaman terhadap bahasa yang digunakan guru sebelum mengikuti pelatihan masih kurang. Oleh karena itu, walaupun pelatihan ini menggunakan metode konvensional, perubahan yang terjadi setelah mengiluti pelatihan cukup signifikan.

Penentuan indikator pelatihan didasarkan pada teori dalam penyusunan syrat dinas. Berdasarkan teori, kemampuan menulis surat resmi dapat diukur minimal dari lima kriteria, yaitu kejelasan isi surat, kejelasan urutan surat, kelengkapan bagian-bagian surat, penggunaan ejaan dan tanda baca, dan penggunaan kalimat efektif. Sebetulnya masih ada beberapa indikator yang dapat dijadikan sebagai kriteria kemampuan hmenulis surat resmi, tetapi kelima indikator dapat dijadikan sebagai standar minimal, karena sudah dapat mengukur kemampuan seseorang dalam menulis surat.

\section{KESIMPULAN}

Pelatihan penggunaan ejaan yang disempurnakan dan kalimat efektif pada penulisan surat resmi bagi guru sekolah dasar di wilayah jakarta timur ini cukup berhasil. Hal ini terlihat dari hasil tes kemampuan peserta dalam menulis surat resmi, sebelum (pretest) dan setelah pelatihan (posttest).

Berdasarkan hasil tes awal, peserta yang memiliki kemampuan menulis surat resmi dengan kriteria kejelasan isi surat sebanyak $15 \%$, kejelasan urutan surat sebanyak $10 \%$, kelengkapan bagian-bagian surat sebanyak 10 $\%$, penggunaan ejaan dan tanda baca sebanyak $20 \%$, dan penggunaan kalimat efektif sebanyak 25\%. Persentasi nilai dari masing-masing kriteria terebut meningkat setelah pelatihan dilaksanakan. Berdasarkan hasil tes akhir, kriteria kejelasan isi surat sebesar $70 \%$, kejelasan urutan surat sebesar 65\%, kelengkapan bagian-bagian surat sebesar $80 \%$, penggunaan ejaan dan tanda baca sebesar $70 . \%$, dan penggunaan kalimat efektif sebesar $75 \%$. Perbandingan antara hasil tes awal dengan tes 
akhir, dapat digambarkan dalam bentuk grafik berikut ini.

\section{DAFTAR PUSTAKA}

Amran, Tasai dan Parera, J.D. 1995. Pintar Berbahasa Indonesia. Jakarta: Balai Pustaka

Arifin, Syamsir. 1987. Pedoman Penulisan Surat menyurat Indonesia. Padang: Angkasa Raya.
Ermanto dan Emidar.2010.Pengembangan Kepribadian di Perguruan Tinggi. Padang:UNP Press.SS

Nurdin, Ade. 2005. Intisari Bahasa dan Sastra Indonesia. Bandung: Pustaka Setia.

Sudarsa, dkk. 1992. Surat Menyurat dalam Bahasa indonesia. Jakarta: Departemen Pendidikan dan Kebudayaan. 